\title{
Effect of Relationship Marketing on brand loyalty between customers of Bank Refah Kargaran in Tehran city - Iran
}

\author{
${ }^{1}$ Zahra Poorkarimi kokand, ${ }^{2}$ Zeinolabedin amini sabegh \\ ${ }^{I}$ Student of executive management, Science and Research branch, Islamic Azad University, Saveh, Iran. \\ ${ }^{2}$ Departmen ${ }^{t}$ of Public management, Islamic Azad University, saveh branch, Saveh, Iran
}

\begin{abstract}
In recent years, the banking industry has witnessed intense competition with its lots of opportunities and threats. Customer loyalty is a critical factor to achieve success in today's complex market. Because it increases profits through the barrierto shift the customers' tendency towards rivals and increases the ability inpower of responding to their threats. Using the relationship marketing approach, while developing a longterm relationship with the customer, activities which are important and valuable in their sight can be identified, strengthened and improved and more customers can be attracted and made loyalty to the organization and its brand.Hence, the identification ofrelationship marketing and its foundations is an essential factor for the bank managers. The aim of this study was to investigate the effect of relationship marketing on brand loyalty ofbank's customers. According to Morgan Table, 384 questionnaires consisting of 20 questions in order to test the hypotheses were distributed among customers of Bank Refah Kargaran in four areas of Tehran. The method was descriptive survey method and sampling method was a multi-stage random sampling. Pearson correlation test and regression and SPSS 16 software were used in order to test hypotheses and analyze the collected data. The results show that variables of Trust - Commitment - Communication, which are the foundations of relationship marketing, have a significant impact on customer satisfaction and brand loyalty.Another finding of the study is that the variable of customer loyalty is an important factor in customer satisfaction.
\end{abstract}

Keywords: Relationship Marketing, Brand Loyalty, Trust, Customer Satisfaction, Commitment, Communication

\section{Introduction}

With the growth of trade and advancement of technology and innovation in industries, competition among enterprises has intensified day by day and client's share is discussed rather than market share in the location and success of companies. Organizations with superior performance in different industries are moving towards customer retention and their loyalty, because most markets are in their mature step, and with the increase of competition, the cost of attracting new customers has also increased, the loss of one client is not only the loss of a sale item, but also it means more than it, losing the entire stream of purchases that the customer is able to do in his/her lifetime. Many organizations have found thattheir life and survival depends on having loyal customers, not merely satisfied or satisfied ones, that it is a key point in continuing companies' activity. On the other hand, organizations are economically and strategically considered as valuable assets, therefor eone of the main objectives of the organization is to have loyal customers. Meanwhile the banking industry is not excluded from this rule and banks also need to seek for various management strategies in order to improve their customers' brand loyalty. To avoid the tendency of customers toward competitors, bank managers should seek to understand the wants and needs of their customers more than everto meet their needs and establish long-term business relationships with them. Using the relationship marketing approach, while developing a long-term relationship with the customer, activities which are important and valuable in their sight can be identified, strengthened and improved and more customers can be attracted and made loyalty to the organization and its brand. Relationship marketing is a concept that has been introduced in the past two decades.In recent years, organizations have found that they should act as a reliable partner to have a sustainable competitive advantage.Relationship marketinghaveforced brand managers to seek formore creativewaysto create a beneficial two-wayrelationshipwith customers andearningtheir brand loyalty. Implementation ofrelationship marketingcanhavea significant impacton thefinancial performanceandprofitabilityof organizations, butdespiteitsimmense importancein thesuccess of thefirms, no much attention has beenpaid on it. Therefore,the main objectiveof thisstudy was to evaluatethe impact ofrelationship marketingonbrandloyaltyofbanks' customers and providesomestrategies forsuccessfully implementing it.

\section{Problem Statement}

Financial services sector has undergone some changes in (banks) that has not experienced before in history. It is not surprisingthat in this turbulent environment with accelerating changes, financial institutions change their reaction to marker to retain key and profitable customers and focus more on customers and good relationships with them. The theory of traditional or classical marketing mostly was paying attention todoing 
transaction and keeping the customers and had no attention to customers. But with the development of competition and saturation ofmany markets and continuous changes in environment and combination of population, organizations are faced with the fact that today they are not faced with a growing economy and growing markets like past. Today, each client has its own value and now, the organizations should fight to gain a greater share from stable or declining market. Relationship marketing is a set of activities that aim to create long-term and beneficial links between an organization and its customers to provide mutual benefits for the parties. Bin and Bella believe that relationship marketing tries to create the maximum value for customers through the collection and dissemination of information and creation of knowledge and insight about the needs and demands of customers that it is accomplished through relationships with customers. Research has shown that the use of relationship marketing by organization is positively correlated with its performance, employees' satisfaction, success of new product and gaining competitive advantage in the market environment. Research in the area of relationship marketing has also added other cases, such as trust, commitment, communication, shared values, cooperation and social relationships with customersto its literature. Relationship marketing activities in the banking sector are very important.Forcontinued success with organizational customers, banks needtoinveston its relationship marketing structure in along termand support tocustomer oriented strategies. On the other hand, brand loyaltyplays an important roleincreatinglong-term benefitsfor theorganization, becauseloyal customersdo not need tohaveextensivepromotionalefforts and gladlyintendtopaymoreforbenefits and quality of their favoritebrand.Organizations can achieve larger share of the market with the help of brand loyalty, because loyal customers buy the brand frequently and resist against situational factors and competitors' marketing efforts. Loyalty, in addition to the increase of market share, leads to the organization'sdemand for a higher price than competitors and increases the mouth to mouth positive advertisements among customers. There are many definitions of brand loyalty.Brand loyalty isa rather biased behavior (in purchase or recommendation to purchase) that the person finds about the brand during the timeand this behavior causes that the person finds a specific orientation towardsthe brand among other brandscomingto mindduring decisionmaking and evaluationprocesses. This reaction is a function of person's psychological mental processes. Brand loyalty is created when a customer believes that a brand reflects or reinforces some aspects of his/her perception from the name. David Aaker believes that brand loyalty represents the chance of joiningcustomer to a competitor's brand, especially when the brand makes changes in prices and product features. Thisresearchaimsto determine howther elationship marketing, which is measured through itsthree important dimensions, namely consumers' trust in bank's employees, employees' commitment during service, and communication skills, canaffect customers' satisfaction andbrand loyalty.

\section{Research hypotheses}

In this study,one main hypothesisand foursub-hypothesesisraised as follows:

\section{The main hypothesis:}

- There is a relationship between relationship marketing and brand loyalty.

\section{Sub-hypotheses:}

- There is a relationship between trustandbr and loyalty.

- There is a relationship between commitment and brand loyalty.

- There is a relationship between communication and brand loyalty.

\section{Test of research hypotheses:}

In order to test theresearch hypotheses, we intendto usetheparametrictests (such as regression and Pearson correlation), therefore thefirst requirementis the normality of datadistribution, and hence at first thenormalityofdependent variabledatawill bediscussed.Kolmogorov-Smirnov testwas used toinvestigate thenormality of distribution ofdata related to variables; theresultsare showninthe following table:

- Table 1: The normalityofdistribution ofresearch variables based onKolmogorov-Smirnov test

\begin{tabular}{|c|c|c|c|c|c|c|}
\hline Description & Trust & $\begin{array}{c}\text { Customer's } \\
\text { Satisfaction }\end{array}$ & Commitment & Communication & $\begin{array}{c}\text { Brand } \\
\text { Loyalty }\end{array}$ & $\begin{array}{c}\text { Relationship } \\
\text { Marketing }\end{array}$ \\
\hline \hline $\mathrm{Z}$ & 1.155 & 1.341 & 1.128 & 1.160 & 0.771 & 1.108 \\
\hline $\begin{array}{c}\text { Significance } \\
\text { Level }\end{array}$ & 0.142 & 0.055 & 0.157 & 0.136 & 0.592 & 0.251 \\
\hline
\end{tabular}


If the significant levelof Kolmogrov-Smirnov testis more than0.05, we can conclude that distribution ofdatarelative to variable does notvarysignificantlywithnormal distribution. Asreportedinthe above table, significance level ofall research variablesis calculated greaterthan 0.05 . Sowe can say that distribution ofdatarelated to variableshas nosignificant difference with a normal distribution.

\section{The first sub-hypotheses:}

There is a relationshipbetweentrustandbrand loyalty.

According to the obtainedresults, Pearson correlation coefficientfor thevariablesof trust andbrand loyaltyisas follows.

\begin{tabular}{|l|l|}
\hline Pearson correlation coefficient & 0.856 \\
\hline Significance Level & 0.000 \\
\hline
\end{tabular}

Bivariate regressionis used to investigatethe relationshipbetweentrustandbrand loyalty.

The general discriminants ofregression analysisof the relationship betweentrustandbrand loyalty

\begin{tabular}{|c|c|c|c|c|c|}
\hline $\begin{array}{l}\text { Regression } \\
\text { Model }\end{array}$ & $\begin{array}{c}\text { Correlation } \\
\text { Coefficient } \\
\text { R }\end{array}$ & $\begin{array}{c}\begin{array}{c}\text { Determination } \\
\text { Coefficient } \\
\text { R2 }\end{array} \\
\text {. }\end{array}$ & $\begin{array}{c}\text { Adjusted } \\
\text { Correlation } \\
\text { Coefficient } \\
\text { R }\end{array}$ & $\mathrm{F}$ & $\begin{array}{c}\text { Significance } \\
\text { Level }\end{array}$ \\
\hline$\overline{1} 1$ & 0.856 & 0.732 & 0.731 & 793.580 & 0.000 \\
\hline
\end{tabular}

The findings of aboveregression coefficient table show the relationship betweenconsumers' trust and their brand loyalty. Correlation coefficientbetween thesetwo variablesis 0.856 , that giventhesignificant level of 0.000 which is lessthan 0.05 (level of test error), it should be said there is a strong significantrelationshipbetweenconsumers' trust andbrand loyalty. According to the amount of determination coefficient $\mathrm{R} 2=0.732$ it can be said that about 73percentof thechange inbrand loyaltycould be explainedbycustomers' trust.

\section{The second sub-hypotheses:}

There is a relationshipbetweencommitmentandbrand loyalty.

Bivariate regressionis used to investigatethe relationshipbetween customers' commitmentandbrand loyalty. According to the table 4-10, Pearson correlation coefficientfor thevariablesof commitmentandbrand loyaltyisas follows.

\begin{tabular}{|r|r|}
\hline Pearson correlation coefficient & 0.885 \\
\hline Significance Level & 0.000 \\
\hline
\end{tabular}

The general discriminants ofregression analysisof the relationship betweencommitmentandbrand loyalty

\begin{tabular}{|c|c|c|c|c|c|}
\hline $\begin{array}{l}\text { Regression } \\
\text { Model }\end{array}$ & $\begin{array}{c}\text { Correlation } \\
\text { Coefficient } \\
\text { R }\end{array}$ & $\begin{array}{c}\text { Determination } \\
\text { Coefficient } \\
\text { R2 }\end{array}$ & $\begin{array}{c}\text { Adjusted } \\
\text { Correlation } \\
\text { Coefficient } \\
\text { R }\end{array}$ & $\mathrm{F}$ & $\begin{array}{c}\text { Significance } \\
\text { Level }\end{array}$ \\
\hline 1 & 0.885 & 0.783 & 0.783 & 1049.251 & 0.000 \\
\hline
\end{tabular}

The findings of aboveregression coefficient table show the relationship betweenconsumers' commitmentand their brand loyalty. Correlation coefficientbetween thesetwo variablesis 0.886 , that giventhesignificant level of 0.000 which is lessthan 0.05 (level of test error), it should be said there is a strong significantrelationshipbetweenconsumers' commitmentandbrand loyalty. According to the amount of determination coefficient $\mathrm{R} 2=0.855$ it can be said that about 78percentof thechange inbrand loyaltycould be explainedbycustomers' commitment.

Regression coefficientof the relationship betweencommitmentandbrand loyalty

\begin{tabular}{|r|c|c|c|c|c|}
\hline Regression Model & $\begin{array}{c}\text { Regression } \\
\text { coefficient }\end{array}$ & Standard Error & Standard $\beta$ & $\mathrm{t}$ & $\begin{array}{c}\text { Significance } \\
\text { Level }\end{array}$ \\
\hline \hline Constant coefficient & -0.182 & 1.018 & \multirow{2}{*}{0.885} & -0.179 & 0.000 \\
\hline Commitment & 1.278 & 0.039 & & 32.392 & 0.000 \\
\hline
\end{tabular}

According to the above regression findings ( $\mathrm{Sig}=0.000, \beta=0.885)$ it can be said that consumers' commitment has 
a significant effect on brand loyalty and there is 0.885 units increase in brand loyalty for one unit increase in commitment,as a result, there is no reason to rejectthe hypothesis.

\section{The third sub-hypotheses:}

There is a relationshipbetweencommunicationandbrand loyalty.

Bivariate regressionis used to investigatethe relationshipbetweencommitmentandbrand loyalty. According to the table 4-10, Pearson correlation coefficientfor thevariablesof communicationandbrand loyaltyisas follows.

\begin{tabular}{|r|r|}
\hline Pearson correlation coefficient & 0.776 \\
\hline Significance Level & 0.000 \\
\hline
\end{tabular}

Bivariate regressionis used to investigatethe relationshipbetweencommunicationandbrand loyalty.

The general discriminants ofregression analysisof the relationship betweencommunicationandbrand loyalty

\begin{tabular}{|c|c|c|c|c|c|}
\hline Regression Model & $\begin{array}{c}\text { Correlation } \\
\text { Coefficient } \\
\text { R }\end{array}$ & $\begin{array}{c}\text { Determinatio } \\
\text { n Coefficient }\end{array}$ & $\begin{array}{c}\text { Adjusted } \\
\text { Correlation } \\
\text { Coefficient } \\
\text { R }\end{array}$ & R2 & S ignificance Level \\
\hline \hline 1 & 0.776 & 0.603 & 0.601 & 439.602 & 0.000 \\
\hline
\end{tabular}

The findings of aboveregression coefficient table show the relationship betweencommunicationandbrand loyalty. Correlation coefficientbetween thesetwo variablesis0.776, that according to thesignificant level, it should be said there is a strong significantrelationshipbetweencommunicationandbrand loyalty. According to the amount of determination coefficient $\mathrm{R} 2=0.603$ it can be said that about 60percentof thechange inbrand loyaltycould be explainedbycommunication.

Regression coefficientof the relationship betweencommunication andbrand loyalty

\begin{tabular}{|r|c|c|c|c|c|}
\hline Regression Model & $\begin{array}{c}\text { Regression } \\
\text { coefficient }\end{array}$ & Standard Error & Standard $\beta$ & $\mathrm{t}$ & $\begin{array}{c}\text { Significance } \\
\text { Level }\end{array}$ \\
\hline \hline Constant coefficient & -1.306 & 1.615 & \multirow{2}{*}{0.776} & -0.809 & 0.419 \\
\hline communication & 1.563 & 0.075 & & 20.967 & 0.000 \\
\hline
\end{tabular}

According to the above regression findings $(\operatorname{Sig}=0.000, \beta=0.776)$ it can be said that communication has a significant effect on brand loyalty and there is 0.776 units increase in brand loyalty for one unit increase in commitment,as a result, there is no reason to rejectthe hypothesis.

\section{The main hypothesis:}

There is a relationshipbetweenrelationship marketingandbrand loyalty.

According to the obtained results, Pearson correlation coefficientfor thevariablesof relationship marketingandbrand loyaltyisas follows.

\begin{tabular}{|r|r|}
\hline Pearson correlation coefficient & 0.903 \\
\hline Significance Level & 0.000 \\
\hline
\end{tabular}

Bivariate regressionis used to investigatethe relationshipbetweenrelationship marketingandbrand loyalty.

The general discriminants ofregression analysisof the relationship betweenrelationship marketingandbrand loyalty

\begin{tabular}{|c|c|c|c|c|c|}
\hline Regression Model & $\begin{array}{c}\text { Correlation } \\
\text { Coefficient } \\
\mathrm{R}\end{array}$ & $\begin{array}{c}\text { Determinatio } \\
\text { n Coefficient } \\
\mathrm{R} 2 \\
\end{array}$ & $\begin{array}{c}\text { Adjusted } \\
\text { Correlation } \\
\text { Coefficient } \\
\mathrm{R} \\
\end{array}$ & $\mathrm{F}$ & Significance Level \\
\hline 1 & 0.903 & 0.815 & 0.814 & 1277.884 & 0.000 \\
\hline
\end{tabular}

The findings of aboveregression coefficient table show the relationship betweenrelationship marketingandbrand loyalty. Correlation coefficientbetween thesetwo variablesis 0.903 , that according to thesignificant level, it 
should be said there is a strong significantrelationshipbetweenrelationship marketingandbrand loyalty. According to the amount of determination coefficient $\mathrm{R} 2=0.815$ it can be said that about 81 percentof thechange inbrand loyaltycould be explainedbyrelationship marketing.

Regression coefficientof the relationship betweenrelationship marketingandbrand loyalty

\begin{tabular}{|r|c|c|c|c|c|}
\hline Regression Model & $\begin{array}{c}\text { Regression } \\
\text { coefficient }\end{array}$ & Standard Error & Standard $\beta$ & $\mathrm{t}$ & $\begin{array}{c}\text { Significance } \\
\text { Level }\end{array}$ \\
\hline \hline $\begin{array}{r}\text { Constant } \\
\text { coefficient }\end{array}$ & -8.246 & 1.144 & & -7.223 & 0.000 \\
\hline $\begin{array}{r}\text { relationship } \\
\text { marketing }\end{array}$ & 0.533 & 0.015 & 0.903 & 35.748 & 0.000 \\
\end{tabular}

\section{Conclusion}

The resultsofPearson correlationtest infirstsub-hypothesis showed that there is a positive and significant relationship betweencustomers' trust and their brand loyalty.According totheregression $(\beta=0.856 \mathrm{andSig}=$ 0.000 )we can say thatcustomers' trust has asignificant effect onbrand loyalty and there is 0.856 units increase in brand loyalty for one unit increase in customers' trust andas a result, there is no reason to rejectthe hypothesis. The resultsofPearson correlationtest insecondsub-hypothesis showed that there is a positive and significant relationship betweencustomers' commitment and their brand loyalty. According totheregression $(\beta=0.885 \mathrm{andSig}$ $=0.000$ )we can say thatcustomers' commitment has asignificant effect onbrand loyalty and there is 0.885 units increase in brand loyalty for one unit increase in customers' commitment and as a result, there is no reason to rejectthe hypothesis. The resultsofPearson correlationtest inthirdsub-hypothesis showed that there is a positive and significant relationship betweencustomers' communication and their brand loyalty.According totheregression $(\beta=0.776$ andSig $=0.000)$ we can say thatcustomers' communication has asignificant effect onbrand loyalty and there is 0.776 units increase in brand loyalty for one unit increase in customers' communication and as a result, there is no reason to rejectthe hypothesis. As a result of confirming subhypotheses and provided results, the main hypothesis was also confirmed and it was concluded that relationship marketing has a significant effect on brand loyalty.

\section{Reference}

[1]. Alrubaiee.L, Al-Nazer, N.(2010). "Investigate the Impact of Relationship Marketing Orientation on Customer Loyalty: The Customer's Perspective".International Journal of Marketing Studies, Vol.2, No.1.

[2]. HUO, Y., XU, Y. (2011). Research on Relationship between Customer Satisfaction and Customer Loyalty in the Banking Service Industry.International Conference on Computer Science and Service System (CSSS), pp.660-663.

[3]. Jalilvand, M.R., Ebrahimabadi, F., Samiei, N. (2011). The Impact of Branding on Customers' Attitudes toward Banking Services ( The Case of Iran's Melli Bank). Journal of International Business and Management, Vol.2, No.1, pp. 186-197.

[4]. Mohsan, F., Nawaz, M.M., Khan, M.S. et al. (2011). Impact of Customer Satisfaction on Customer Loyalty and Intentions to Switch: Evidence from Banking Sector of Pakistan. International Journal of Business and Social Science, Vol. 2, No. 16, pp.263-270.

[5]. Olotu, A.O., Maclayton, D.W., Opara, B.C. (2010). An Empirical Study of Relationship Marketing Orientation and Bank Performance.Research Journal of International Studies, Issue 16.

[6]. Payne, A., Christopher, M., Clarh, M., Peck, H. (1995). Relationship Marketing for Competetive Advantages. Butter worthHeinemann,UK.

[7]. Wan Omar, M., Mohd Ali, M. (2010). Brand Loyalty and Relationship Marketing in Islamic Banking System. Journal of Canadian Social Science, Vol.6, No.1, pp.25-32. 